\title{
Hubungan antara dinamika suhu tubuh dan leukosit perifer dengan skala skor FOUR penderita cedera otak risiko tinggi
}

\author{
Mulyoni Polapa \\ Eko Prasetyo \\ Maximillian Ch. Oley
}

\author{
Divisi Bedah Saraf Bagian Bedah Fakultas Kedokteran Universitas Sam Ratulangi \\ RSUP Prof. Dr. R. D. Kandou Manado \\ Email: yonimulyoni@yahoo.com
}

\begin{abstract}
One third of patients died in the hospital are patients with secondary brain injury associated with increased intracranial pressure as the main clinical manifestation. Body temperature, inflammatory response, and brain injury are strongly correlated each other. The responses manifest as hyperthermia, leukocytosis, and disturbances in respiratory and heart rates. Prognosis determination is very important at the time in Intensive Care Unit. FOUR score scale involves four components, as follows: eye response, motor response, brainstem reflexes, and respiration. This study was aimed to obtain the relationship between body temperature dynamic and total peripheral leucocyte with FOUR score in patients with high risk brain injury due to trauma. This was an observational analytical study with a cross sectional design. There were 38 patients that fulfilled the inclusion criteria at Prof Dr. R. D. Kandou Hospital Manado. The relationships between body temperature dynamic and total peripheral leukocyte with FOUR score were statistically analyzed with Pearson regression and correlation analysis (SPSS Version 22.0). The results showed that there was a negative correlation between body temperature dynamic and FOUR score $(P=0.03)$ meanwhile the correlation between total peripheral leukocyte and FOUR score was not significant $(P=$ 0.420). Conclusion: Body temperature dynamic dan total peripheral leucocyte can be included in the protocol of the management of patients with brain injury.
\end{abstract}

Keywords: brain injury, neuroinflammation, FOUR score, temperature, leucocyte

\begin{abstract}
Abstrak: Sepertiga dari pasien meninggal di rumah sakit ialah pasien yang mengalami cedera otak sekunder dengan peningkatan tekanan intrakranial sebagai manifestasi klinik utama. Suhu tubuh, respon inflamasi, dan cedera otak sangat erat kaitannya. Respon ini dimanifestasikan dengan hipertermia, leukositosis, serta gangguan respirasi dan denyut jantung. Penentuan prognosis pada saat perawatan di Unit Perawatan Intensif sangat berperan. Skala skor FOUR (Full outline unresponsiveness) melibatkan penilaian dari empat komponen berikut, yaitu: respon mata, respon motorik, refleks batang otak dan pernapasan. Penelitian ini bertujuan untuk mencari hubungan antara dinamika suhu tubuh dan total leukosit perifer dengan skor FOUR pada pasien cedera otak risiko tinggi karena trauma. Jenis penelitian ini observasional korelatif analitik dengan desain potong lintang. Terdapat 38 pasien cedera otak resiko tinggi yang memenuhi kriteria inklusi di RSUP Prof. Dr. R. D. Kandou Manado. Hubungan antara dinamika suhu tubuh dan total lekosit perifer dengan skor FOUR dianalisis dengan analisis regresi korelasi Pearson menggunakan SPSS Versi 22.0. Hasil penelitian mendapatkan hubungan negatif antara dinamika suhu tubuh dengan skala skor FOUR penderita cedera otak risiko tinggi $(P=0,03)$ sedangkan hubungan antara leukosit perifer dan skala skor FOUR secara statistik tidak bermakna $(P=0,420)$. Simpulan: Penilaian dinamika suhu tubuh dan leukosit perifer dapat dijadikan pedoman dalam penatalaksanaan penderita cedera otak.
\end{abstract}

Kata kunci: cedera otak, neuroinflamasi, skor FOUR, suhu, lekosit 
Trauma merupakan sebab kematian utama kelompok umur di bawah 45 tahun di negara maju dan negara berkembang. Cedera otak akibat trauma merupakan penyebab utama kematian pada usia muda di Amerika dan Eropa. ${ }^{1}$ Sepertiga dari pasien meninggal di rumah sakit ialah pasien yang mengalami cedera otak sekunder dengan peningkatan tekanan intrakranial sebagai manifestasi klinik utama. Angka kejadian cedera otak mencapai $35 \%$ sampai $50 \%$ dari semua pasien trauma multipel. ${ }^{2,3}$

Penyebab cedera otak karena trauma terbanyak akibat kecelakaan kendaraan bermotor $(50 \%)$, jatuh $(21 \%)$, olahraga $(10 \%)$; sisanya akibat kejadian lain. ${ }^{3} \mathrm{Di}$ Indonesia, dari data rekam medis di RSUPN Dr. Cipto Mangunkusumo Jakarta tahun 1998 tercatat penderita cedera otak karena trauma sebanyak 1091 orang dengan cedera otak resiko tinggi mencapai 137 orang $(10 \%)$. Angka kematian kurang lebih sepertiganya dengan perdarahan intrakranial mencapai $50 \%$ dari seluruh kematian. ${ }^{4}$

Pada dasarnya perkembangan kerusakan otak setelah cedera otak merupakan hasil kombinasi dari kerusakan primer dan kerusakan sekunder. Cedera primer merupakan akibat langsung trauma yang menimbulkan kerusakan primer atau kerusakan mekanis sedangkan cedera sekunder merupakan proses patologik yang dimulai pada saat cedera dengan presentasi klinis tertunda. Cedera otak sekunder dideskripsikan sebagai konsekuensi gangguan fisiologik, seperti iskemia, reperfusi, dan hipoksia pada area otak yang berisiko, beberapa saat setelah terjadinya cedera awal (cedera otak primer). Cedera otak sekunder peka terhadap terapi dan proses terjadinya masih dapat dicegah. ${ }^{5}$

Studi klinik dan eksperimental tahuntahun terakhir melaporkan peningkatan level mediator proinflamasi seperti platelet activating factor, radikal bebas, dan komponen dari asam arahidonat di serum, parenkim, dan cairan serobrospinal (CSS) segera setelah trauma kepala. Interleukin-6, tumor nekrosis faktor, dan sitokin, memuncak di dalam CSS pada hari pertama setelah cedera otak. Contoh eksperimental dari cedera otak menunjukkan bahwa sitokin ditemukan dan dihasilkan di otak setelah terjadi cedera otak, dan penghambatan faktor tersebut dapat menjadi pelindung bagi otak. Leukosit seperti halnya sitokin memegang peranan penting terhadap skenario tersebut. Leukosit menghasilkan banyak mediator inflamasi setelah terjadi cedera otak dan diaktifkan sebagai respon terhadap cedera otak. Akumulasi lekosit dalam parenkim otak telah ditunjukkan dalam 4 sampai 48 jam pertama setelah cedera otak. Hanya sedikit yang diketahui tentang kemungkinan peran leukosit setelah cedera otak. Kenaikan jumlah lekosit tersebut berhubungan dengan luaran yang buruk pada pasien cedera otak. ${ }^{6,7}$

Penilaian suhu tubuh merupakan indikator sederhana, obyektif, dan akurat dari suatu status fisiologik dengan sedikit pengaruh stimulus eksternal dan psikogenik dibanding tanda vital lainnya seperti nadi, respirasi, dan tekanan darah. Untuk alasan ini, penentuan suhu tubuh membantu memperkirakan beratnya penyakit, sumbernya, lamanya, dan efek pengobatan.

Menurut Greenberg, variasi suhu sangat erat kaitannya dengan cedera neuronal meliputi penurunan pengeluaran glutamat, mekanisme radikal bebas, depolarisasi iskemik, dan aktifitas kinase, terjaganya aliran darah ke otak dan sitoskeleton, serta penekanan mekanisme inflamasi. Penelitian pada hewan coba menunjukkan bahwa dengan menurunkan suhu dapat meningkatkan level glutamat dan menghindari perluasan iskemi. ${ }^{8,9}$ Suhu tubuh, respon inflamasi dan cedera otak berkaitan sangat erat. ${ }^{6-9}$

Penentuan prognosis pada saat perawatan di Unit Perawatan Intensif merupakan suatu hal yang perlu diperhatikan. Dengan mengetahui prediksi prognosis maka penanganan menjadi lebih optimal dan motivasi untuk menangani secara maksimal lebih tinggi. Selama ini telah dikenal sistem skoring yang sudah 
dipergunakan secara luas yaitu Glasgow Coma Scale (GCS) atau modifikasi GCS namun memiliki keterbatasan yaitu komponen verbal pasien yang berada dalam keadaan koma dan terintubasi tidak dapat dinilai. Hasil penelitian menunjukkan sekitar 20\%-48\% pasien dengan GCS sebagai alat untuk menilai kesadaran, menjadi kurang bermanfaat karena diintubasi. $^{10}$

Wijdicks $(2005)^{11}$ menerbitkan skala koma baru yaitu skor FOUR (Full Outline UnResponsiveness) yang melibatkan penilaian dari 4 komponen berikut, masingmasing pada skala dengan nilai maksimal empat: respon mata, respon motorik, refleks batang otak, dan pernapasan (Gambar 1). Skala ini mempu mendeteksi kondisi seperti lock in syndrome dan keadaan vegetatif yang tidak terdeteksi dengan GCS. ${ }^{11-12}$

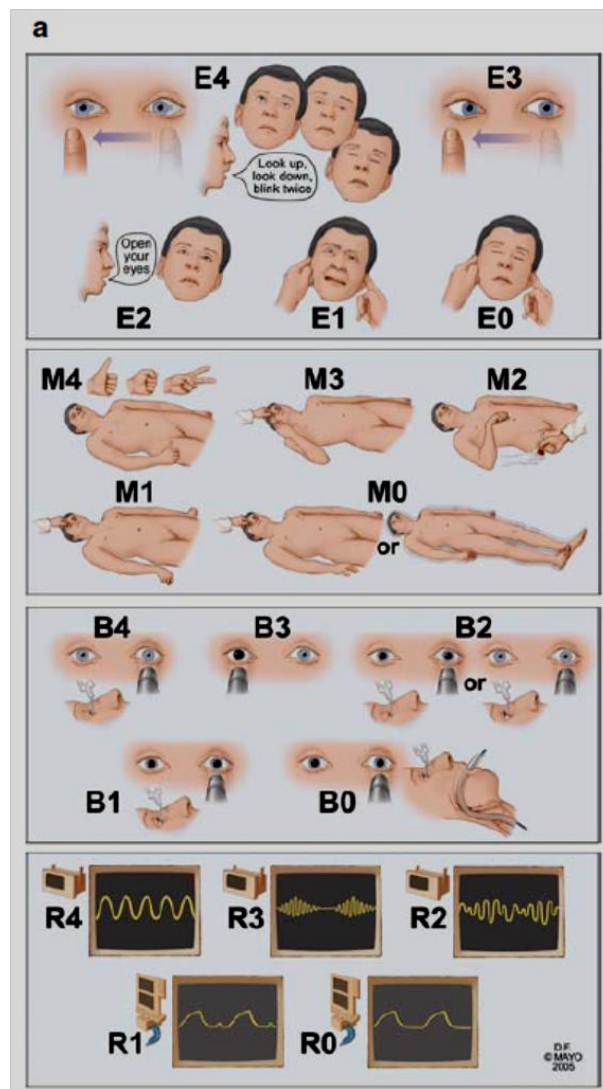

b

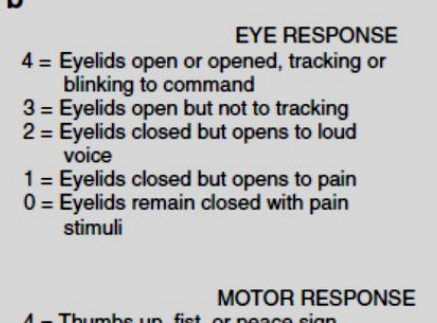

$4=$ Thumbs up, fist, or peace sign

$3=$ Localizing to pain

2 = Flexion response to pain

$1=$ Extension response

$0=$ No response to pain or generalized

Myoclonus status

BRAINSTEM REFLEXES

$4=$ Pupil and corneal reflexes present $3=$ One pupil wide and fixed

$2=$ Pupil or corneal reflexes absent

$2=$ Pupil or corneal reflexes absent
$1=$ Pupil and corneal reflexes absent

$1=$ Pupil and corneal reflexes absent
$0=$ Absent pupil, corneal, or cough

reflex

$4=$ Regular breathing pattern

$3=$ Cheyn pattern

$3=$ Cheyne-Stokes breathing pattern

$1=$ Trigglar breathing

Triggers ventilator or breathes

$0=$ Apnea or breathes at ventilator rate

Gambar 1. FOUR score visual aid. Sumber: Wijdicks EF et al, 2005. ${ }^{11}$

Pengelolaan suhu tubuh dengan perlakuan hipotermi saat ini merupakan salah satu strategi dalam penanganan pasien cedera otak risiko tinggi di unit perawatan intensif. Hubungan antara perubahan suhu tubuh dengan manifestasi respon inflamasi lainnya belum banyak diketahui. ${ }^{8}$ Penelitian Suzuki et al. ${ }^{13}$ menunjukkan bahwa terdapat hubungan antara total leukosit perifer dan suhu tubuh dengan volume perdarahan dan luaran pada pasien hypertensive intracerebral haemorrhage.

Penelitian ini bertujuan untuk mencari keterkaitan antara dinamika suhu tubuh dan total lekosit perifer dengan skor FOUR pada pasien cedera otak risiko tinggi karena trauma di RSUP Prof. Dr. R. D. Kandou.

\section{METODE PENELITIAN}

Jenis penelitian ini ialah observasional korelatif dengan desain potong lintang 
untuk menganalisis hubungan antara dinamika suhu tubuh dan total lekosit perifer dengan skor FOUR pada pasien cedera otak resiko tinggi di IRDB RSUP Prof. Dr. R. D. Kandou Manado. Penelitian dilaksanakan sejak Desember 2015 sampai dengan Maret 2016.

Populasi penelitian ialah semua penderita cedera otak risiko tinggi yang didiagnosis berdasarkan pemeriksaan klinis dan neurologis. Sampel ialah penderita cedera otak risiko tinggi yang datang ke RSUP Prof. Dr. R. D. Kandou serta memenuhi kriteria inklusi dan ekslusi. Kriteria inklusi ialah penderita cedera otak risiko tinggi karena trauma yang datang di IRDB RSUP Prof Dr. R. D. Kandou, berusia $\geq 10$ tahun, dan tidak menjalani penanganan operatif sedangkan kriteria eksklusi ialah penderita cedera otak risiko tinggi dengan trauma multipel, waktu trauma $>24$ jam, disertai penyakit infeksi, dan menolak untuk dijadikan subjek penelitian

Penderita cedera otak risiko tinggi kurang dari 24 jam setelah tiba di IRDB diperiksa dan ditangani sesuai ATLS. Tingkat kesadaran dinilai dengan skor FOUR. Dilakukan pemeriksaan suhu tubuh dan total lekosit perifer sesaat setelah penderita masuk rumah sakit dan setiap 24 jam setelah trauma dalam waktu 72 jam pertama. Hubungan antara dinamika suhu tubuh dan total lekosit perifer dengan skor FOUR dianalisis dengan regresi korelasi Pearson (SPSS Versi 11.0).

\section{HASIL PENELITIAN}

Pada penelitian ini terdapat 38 penderita yang diklasifikasikan dalam cedera otak risiko tinggi yang memenuhi kriteria inklusi sebagai subjek penelitian.

Distribusi penderita menurut jenis kelamin ialah sebanyak $81,6 \%$ laki laki dan $18,4 \%$ perempuan (Tabel 1 ).

Tabel 1. Distribusi penderita menurut jenis kelamin

\begin{tabular}{cc}
\hline Jenis kelamin & $\mathbf{n}(\boldsymbol{\%})$ \\
\hline Laki-laki & $31(81,6)$ \\
Perempuan & $7(18,4)$ \\
Total & $38(100)$ \\
\hline
\end{tabular}

Tabel 2 memperlihatkan hasil analisis statistik deskriptif variabel skor FOUR, suhu tubuh, dan leukosit perifer. Skor FOUR terendah ialah 2 dan tertinggi ialah 7 dengan rerata 5,3. Rerata suhu tubuh saat pemeriksaan awal $\left(\mathrm{T}^{0}\right)$ ialah $37,4^{0} \mathrm{C}$. Rerata pemeriksaan suhu tubuh 24 jam pasca trauma $\left(\mathrm{T}^{1}\right)$ ialah $37,8^{0} \mathrm{C}$. Rerata pemeriksaan suhu tubuh setelah 48 jam $\left(\mathrm{T}^{2}\right)$ ialah $38,3^{\circ} \mathrm{C}$. Rerata total lekosit saat pemeriksaan awal $\left(\mathrm{L}^{0}\right)$ ialah $20,6 \times 10^{3} \mu \mathrm{L}$. Rerata total lekosit 24 jam pasca trauma $\left(\mathrm{L}^{1}\right)$ ialah $22,4 \times 10^{3} \mu \mathrm{L}$. Rerata total lekosit setelah 48 jam pasca trauma $\left(\mathrm{L}^{2}\right)$ ialah $24,8 \times 10^{3} \mu \mathrm{L}$.

Tabel 2. Analisis statistik deskriptif variabel skor FOUR, suhu tubuh, dan leukosit

\begin{tabular}{ccccc}
\hline Variabel & Minimum & Maksimum & Rerata & SB \\
\hline Skor FOUR & 2 & 7 & 5,32 & 1,757 \\
T0 & 36,0 & 38,7 & 37,405 & 0,6649 \\
T1 & 36,4 & 39,2 & 37,787 & 0.7072 \\
T2 & 36,8 & 40,0 & 38,300 & 0,7594 \\
Rerata suhu & 36,5 & 39,17 & 37,8307 & 0,66384 \\
L0 & 7,1 & 52,0 & 20,639 & 8,5520 \\
L1 & 8,8 & 36,7 & 22,432 & 7,0870 \\
L2 & 14,0 & 36,8 & 24,821 & 6,8328 \\
Rerata leukosit & 11,2 & 37,00 & 22,6307 & 6,2666 \\
\hline
\end{tabular}

* $\mathrm{SB}=$ simpangan baku; $\mathrm{T}=$ suhu tubuh; $\mathrm{L}=$ leukosit 
Hasil analisis koefisien korelasi Pearson hubungan skor FOUR dengan suhu tubuh diperoleh $\mathrm{r}=-0,436$ dengan $P=$ 0,003 . Hasil ini menyatakan ada hubungan negatif yang sangat bermakna antara kedua variabel (Gambar 2).

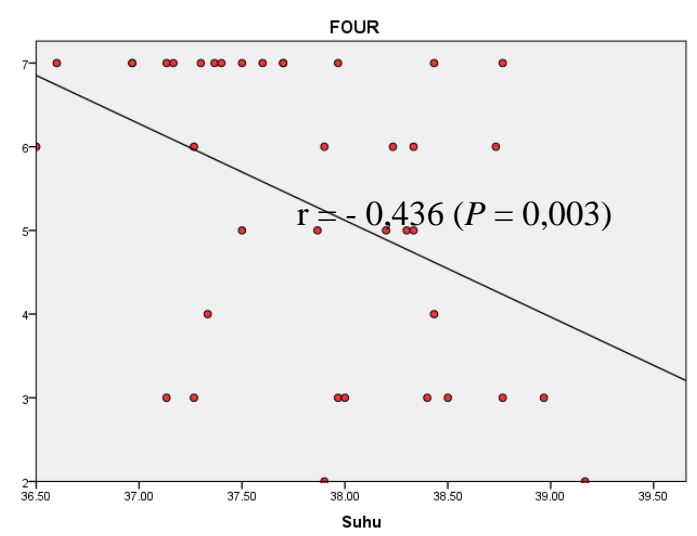

Gambar 2. Scatterplot hubungan suhu tubuh dengan skor FOUR

Hasil analisis koefisien korelasi Pearson hubungan skor FOUR dengan lekosit perifer diperoleh $\mathrm{r}=0,034$ dengan $P$ $=0,420$. Hasil ini menyatakan adanya hubungan positif antara kedua variabel, namun secara statistik tidak bermakna (Gambar 3).

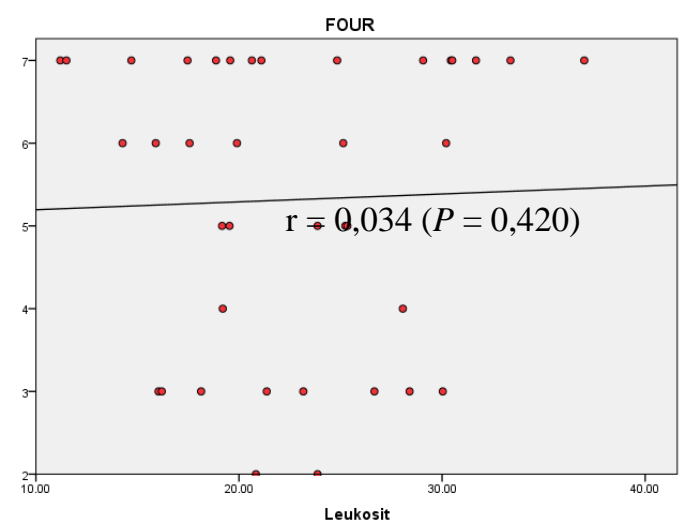

Gambar 3. Scatterplot hubungan lekosit perifer dengan skor FOUR

\section{BAHASAN}

Trauma merupakan sebab kematian utama kelompok umur dibawah 45 tahun di negara maju dan negara berkembang. Kepala merupakan bagian yang paling sering mengalami kerusakan pada pasien trauma multipel. ${ }^{1}$ Penelitian ini dilakukan pada 38 penderita cedera otak risiko tinggi yang terdiri dari 31 laki-laki dan 7 perempuan. Berdasarkan distribusi menurut usia rerata ialah 29 tahun dengan usia termuda 13 tahun dan tertua 79 tahun. Menurut Jennett, ${ }^{14}$ sebagian besar penderita cedera otak di AS dan Skotlandia ialah kelompok umur 20 tahun.

Penentuan prognosis saat perawatan penderita cedera otak risiko tinggi di Unit Perawatan Intensif perlu mendapat perhatian. Dengan mengetahui prognosis maka penanganan menjadi lebih optimal dan motivasi untuk menangani secara maksimal lebih tinggi.

Suhu tubuh, respon inflamasi dan cedera otak sangat erat kaitannya. Respon terhadap cedera antara lain respon neuroendokrin secara klasik terhadap cedera telah diteliti secara luas. Respon ini dimanifestasikan dengan hipertermia, leukositosis, gangguan respirasi, dan denyut jantung. Respon-respon mediator inflamasi terhadap infeksi dan cedera traumatik tidak berbeda. Respon sitokin dengan adanya hipertermia, leukositosis, hiperventilasi, dan takikardi sering terlihat pada cedera yang merujuk pada SIRS tanpa identifikasi proses infeksi. ${ }^{6-9}$

Suhu tubuh, respon infamasi dan cedera otak sangat erat kaitannya. Respon terhadap cedera terutama respon neuroendokrin klasik terhadap cedera telah secara luas diteliti. Respon ini dimanifestasikan dengan hipertermia, lekositosis, gangguan respirasi, dan perubahan denyut jantung. Respon-respon mediator inflamasi terhadap infeksi dan cedera traumatik umumnya tidak berbeda. Respon sitokin disertai hipertermia, leukositosis, hiperventilasi dan takikardi sering terlihat pada cedera otak yang merujuk pada SIRS dan tanpa identifikasi proses infeksi. ${ }^{6-8}$

Pada penelitian ini rerata suhu tubuh penderita cedera otak risiko tinggi saat awal pemeriksaan $37,4^{0} \mathrm{C}$; rerata setelah 24 jam pasca trauma $37,8^{\circ} \mathrm{C}$; dan rerata setelah 48 jam pasca trauma $38,3^{\circ} \mathrm{C}$. Berdasarkan hasil analisis korelasi Pearson didapatkan 
adanya hubungan negatif antara dinamika suhu tubuh dengan skala skor FOUR penderita cedera otak risiko tinggi yang menyatakan makin rendah Skor FOUR, makin tinggi suhu tubuh penderita. Mekanisme peningkatan suhu tubuh pada penderita cedera otak risiko tinggi berhubungan dengan respon neuroinflamasi dan terganggunya pusat termolegulator di hipotalamus. Episode hipertermia pada penderita cedera otak risiko tinggi juga merupakan reaksi inflamasi. Siesjo ${ }^{15}$ mengemukakan adanya suatu kaskade reaksi biokimia yang dicetuskan oleh iskemia yang menyebabkan terjadinya akumulasi radikal bebas. Iskemia yang menyebabkan hipertermia ini terjadi dalam 24-48 jam pasca trauma berkorelasi dengan proses patologi dan luaran penderita cedera otak. Selain itu, hipertermia yang terjadi pada penderita cedera otak seperti cedera aksional difus, dapat sebagai salah satu manifestasi disfungsi otonom. Hipertermia tanpa tanda-tanda infeksi pada penderita cedera otak risiko tinggi mencerminkan kerusakan hipotalamus.

Respons inflamasi, aktivasi sel endotel, dan pelepasan mediator inflamasi pada cedera kepala dapat meningkatkan jumlah leukosit. Cedera kepala berhubungan dengan respons fase akut yang ditandai dengan leukositosis akibat meningkatnya epinefrin dan kortisol. Subramanian A et al. ${ }^{16}$ menjelaskan bahwa pada cedera otak terjadi ruptur traumatik mikrovaskuler yang akan diikuti dengan terjadinya oklusi fisik. Sifat lekosit sukar berubah bentuk bila dibandingkan dengan eritrosit, sehingga dibutuhkan tekanan lebih besar agar lekosit dapat melewati pembuluh darah kapiler yang berdiameter kecil. Pada keadaan dimana perfusi jaringan turun, kapiler berfungsi sebagai filter yang menyaring lekosit sehingga terjadi peningkatan lekosit di darah tepi. Setelah terperangkap di kapiler, terjadi adhesi lekosit dengan endotel sehingga lekosit tidak akan terlepas walaupun tekanan perfusi kembali normal. Menurut penelitian Biagas et al. ${ }^{17}$ lekosit polimorfonuklear akan terakumulasi sampai 48 jam pasca trauma.
Pada penelitian ini rerata pemeriksaan total lekosit perifer awal $20,6 \mathrm{x} .10^{3} / \mu \mathrm{L}$; rerata pemeriksaan lekosit 24 jam pasca trauma $22,4 \times 10^{3} / \mu \mathrm{L}$; dan rerata pemeriksaan lekosit 48 jam pasca trauma $24,8 \times 10^{3} / \mu \mathrm{L}$. Berdasarkan analisis korelasi Pearson didapatkan adanya hubungan antara perubahan total lekosit perifer dengan skala skor FOUR penderita cedera otak risiko tinggi tetapi secara statistik tidak bermakna. Hal ini mungkin disebabkan oleh jumlah kasus dan metode penilitian yang berbeda. Penelitian Suzuki et al. ${ }^{12}$ didapatkan hubungan antara total leukosit dan volume hematoma dengan luaran penderita perdarahan intraserebral, tetapi total lekosit tidak berhubungan dengan gambaran klinis (tingkat kesadaran) penderita cedera otak karena trauma. Hasil penelitian Rovlias dan Kotsou $^{18}$ serta Gurkanlar et al. ${ }^{7}$ mendapatkan korelasi bermakna dengan arah korelasi positif antara tekanan intrakranial berdasarkan gambaran CT-Scan dengan jumlah leukosit darah tepi pada pasien dengan cedera difus (diffuse injury). Gurkanlar et al. ${ }^{7}$ menyatakan bahwa terdapat korelasi antara jumlah leukosit dengan progresi atau abnormalitas pada gambaran CT-Scan. Faktor-faktor yang dapat memengaruhi jumlah total lekosit pada cedera otak adalah proses patologik seperti perdarahan epidural, perdarahan intraserebral, perdarahan subarahnoid dan perdarahan subdural. ${ }^{7}$

Reaksi inflamasi akut yang terjadi karena kerusakan dan aktivasi sel endotel termasuk pada cedera otak karena trauma ditandai dengan penimbunan leukosit dalam jumlah banyak terutama neutrofil. Jumlah neutrofil absolut mungkin dapat menjadi prediktor luaran yang lebih baik daripada jumlah leukosit total pada pasien cedera kepala. Dalam penelitian ini tidak digunakan pemeriksaan hitung jenis leukosit sehingga tidak diketahui jumlah neutrofil absolut.

\section{SIMPULAN}

Berdasarkan hasil penelitian dan bahsan dapat disimpulkan bahwa 
peningkatan suhu tubuh dalam 48 jam pasca trauma penderita cedera otak risiko tinggi berhubungan dengan skala skor FOUR. Penilaian total lekosit dalam 48 jam pertama berhubungan dengan skala skor FOUR penderita cedera otak risiko tinggi meskipun secara statistik tidak bermakna. Penilaian dinamika suhu tubuh dapat menjadi prediktor dalam menilai luaran penderita cedera otak risiko tinggi.

\section{SARAN}

Penilaian dan pengelolaan suhu tubuh dapat menjadi pedoman dalam penatalaksanaan penderita cedera otak risiko tinggi. Diperlukan penelitian lanjutan untuk menilai peran pemeriksaan total lekosit terhadap luaran penderita cedera otak dengan metode dan variabel penelitian yang lain.

\section{DAFTAR PUSTAKA}

1. American colleges of surgeon. Head trauma. Advanced trauma life support for doctor (7th ed). Chicago: Commite on trauma, 2008; p.168-76.

2. Selladuray B, Reilly P. Epidemiology of acute head injury. In: Selladuray B, Reilly P, editors. Initial management of head injury. North Ride: McGraw- Hill, 2007; p. 2-8.

3. Kraus JF, McArthur DL, Jayaraman M. Epidemiology of brain injury. In: Narayan RK, Wilberger JE, Povlishock JT, editors. Neurotrauma. NewYork: McGraw- Hill, 1996; p.13-31.

4. Riyadina W, Suhardi, Permana M. Pola determinan sosiodemografi cedera akibat kecelakaan lalu lintas di Indonesia. Majalah Kedokteran Indonesia. 2009;58;464-72

5. Graham DI. Neuropathology of head injury. In: Narayan RK, Wilberger JE, Povlishock JT, editors. Neurotrauma. New York: McGraw-Hill, 1996; p. 4359.

6. Maximillian R, Max BM, Karl EA. Early white blood cell dynamics after traumatic brain injury; effect on the cerebral microcirculation. J Cereb Blood Flow Metab. 1997;17;1210-20.
7. Gurkanlar D, Lakadamiyali H, Ergun T. Predictive value of leucocytosis in head trauma. Turk Neurosurg. 2009;19: 3:211-5.

8. Huang W, Bonnie W, Kevin J. Brain temprature and its fundamental properties; a review for clinical neuroscientiest. Frontier in neuroscience. 2014;8:1-11.

9. Martha A, Curley Q. Thermal regulation. In: Marry FP, editor. Critical Care Nursing of Infants and Children. Philadelphia: University of Pennsylvania Scholarly Commons, 2001;p. 14.443-59.

10. Greenberg SM. Neuroanatomy and Physiology. Handbook of Neurosurgery (6th ed). New York: Thieme, 2001; p. 68-84.

11. Wijdicks EF, Bamlet WR, Maramattom BV, Manno EM, McClerlland RL. Validation of new coma scale: The four score. Ann Neurol.2005;58:585-93.

12. Stead LG, Wijdicks EFM, Bharga A, Kashyap R, Bellolio F, Nash DL, et al. Validation of a new coma scale, the FOUR score, in the Emergency Department. Neurocrit Care. doi 10.1007/s12028-008-9145-0.

13. Suzuki S, Kelley RA, Dandapani BK, Reyes-Iglesias Y, Dietrich WD, Duncan RC. Acute leukocyte and temperature response in hypertensive intracerebral hemorrhage. Stroke. 1995;26;1020-23.

14. Jennett B. Epidemiology of head injury. J Neurol Neurosurg Psychiatry. 1996;60(4):362-9.

15. Siesjo BK. Lactic acidosis in the brain: occureence, triggering mechanisms and pathophysiologica importance. Ciba Foundation Symposium. 1982;87:77100.

16. Subramanian A, Agrawal D, Pandey RM, Nimiya M, Albert $\mathbf{V}$. The leucocuyte count, immature granulocyte count and immediate outcome in head injury patients. In: Agrawal A, editor. Brain Injury Pathogenesis, monitoring, recovery and mnagment. Rijeka, Croatia: InTech Chapter 7; p. 139-52.

17. Biagas KV, Uhl MW, Schiding JK, Nemoto EJ, Kochanek PM. Assessment of posttraumatic 
polymorphonuclear leucocyte accumulation in rat brain using tissue myeloperoxidase assay and vinblastine treatment. J Neurotrauma. 1992;9(4):363-71.

18. Rovlias A, Kotsou S. The blood leucocyte count and its prognostic significance in severe head injury. Surg Neurol.
2001;55:190-6. 2001.

19. Jusuf WRA, Prasetyo E, Oley MC. Correlation between full outline unresponsiveness score and Glasgow coma scale for severe head injury patients at Prof. Dr. R. D. Kandou General Hospital, Manado-Indonesia. BMJ. 2012:1(2):71-3. 